\title{
Paenibacillus campinasensis sp. nov., a cyclodextrin-producing bacterium isolated in Brazil
}

\author{
Jung-Hoon Yoon, ${ }^{1,2}$ Dong Koo Yim, ${ }^{3}$ Jung-Sook Lee, ${ }^{1}$ Kee-Sun Shin, ${ }^{1}$ \\ Helia Harumi Sato, ${ }^{3}$ Sung Taik Lee, ${ }^{2}$ Yong Kun Park ${ }^{3}$ and Yong-Ha Park ${ }^{1}$
}

\author{
Author for correspondence: Yong-Ha Park. Tel: +82428604620 . Fax: +82428604625. \\ e-mail: yhpark@kribb4680.kribb.re.kr
}

\footnotetext{
1 Korean Collection for Type Cultures (KCTC), Korea Research Institute of Bioscience and Biotechnology (KRIBB), PO Box 115, Yusong, Taejon, Korea

2 Department of Biological Sciences, Korea Advanced Institute of Science and Technology, Taejon, Korea

3 State University of Campinas, College of Food Engineering (UNICAMP), Campinas, SP, CEP 13081970, Brazil
}

\begin{abstract}
An alkaliphilic, endospore-forming bacterium isolated from Brazilian soil was taxonomically studied and is proposed as a new Paenibacillus species. This organism (strain $324^{\top}$ ) was particularly distinguishable from other Paenibacillus species by its ability to grow optimally at pH 10 and $40{ }^{\circ} \mathrm{C}$. The DNA G+C content was $\mathbf{5 0 . 9}$ mol\%. The diamino acid of the cell-wall peptidoglycan was meso-diaminopimelic acid. MK-7 was the predominant menaquinone and anteiso- $C_{15: 0}$ was the major fatty acid. Levels of 165 rDNA similarity between strain $324^{\top}$ and other Paenibacillus species were 90.6-95.9\%. Phylogenetically, strain $324^{\top}$ formed an evolutionary lineage distinct from other species within the evolutionary radiation encompassing the genus Paenibacillus. Based on phenotypic and chemotaxonomic properties, and phylogenetic inference, it is proposed that strain $324^{\top}$ should be placed in the genus Paenibacillus as a new species, Paenibacillus campinasensis. The type strain of the new species is strain $324^{\top}$ ( = KCTC 0364BP').
\end{abstract}

Keywords: Paenibacillus campinasensis, alkaliphilic species, 16S rDNA analysis

\section{INTRODUCTION}

Traditionally, because of the lack of incisive differentiating criteria, all aerobic, endospore-forming organisms have been classified as Bacillus. This lack of differentiating criteria has also hampered recognition of new species and promoted grouping of organisms that failed to show clear-cut differences. Developments in molecular biological methods have suggested that the genus is a phylogenetically heterogeneous taxon. For example, analyses showed a wide range of $\mathrm{G}+\mathrm{C}$ contents (32-69 mol \%) among the DNAs of Bacillus species (Claus \& Berkeley, 1986; Slepecky \& Hemphill, 1991; Stackebrandt \& Liesack, 1993). DNA reassociation studies have shown that many Bacillus species were composites of several genetically unrelated species (Priest, 1981; Slepecky \& Hemphill, 1991; Nakamura, 1996; Shida et al., 1997b). Finally, $16 \mathrm{~S}$ sequencing and resulting phylogenetic studies revealed that the genus Bacillus could be separated into several phylogenetically distinct genera such as Alicyclobacillus (Wisotzkey et al., 1992), Aneurini-

The GenBank accession number for the sequence reported in this paper is AF021924. bacillus (Shida et al., 1996), Brevibacillus (Shida et al., 1996), Halobacillus (Spring et al., 1996) and Paenibacillus (Ash et al., 1993).

A bacterium was isolated in Brazil that was capable of cyclodextrin glycosyltransferase-mediated production of cyclodextrin from starch (Yim et al., 1997). Based on phenotypic characterization, this organism (strain $324^{\mathrm{T}}$ ) was tentatively identified as Bacillus firmus. Shida et al. (1997a) reclassified many Bacillus species as members of the genus Paenibacillus, many species of which excrete diverse assortments of polysaccharidehydrolysing or -synthesizing enzymes. This work suggested that strain $324^{\mathrm{T}}$ could be a Paenibacillus species. To rectify the tenuous classification and to establish its correct taxonomic position, strain $324^{\mathrm{T}}$ was characterized further using 16S rDNA sequencing, chemotaxonomic and additional phenotypic methods. Based on data obtained, a new species, Paenibacillus campinasensis, is proposed.

\section{METHODS}

Bacterial strain and culture conditions. The isolation of strain $324^{\mathrm{T}}$ was described in a previous study (Yim et al., 1997). Strain $324^{\mathrm{T}}$ was cultivated on a medium ( $\left.\mathrm{pH} 10\right)$ that 
contained $\left(1^{-1}\right): 10 \mathrm{~g}$ starch; $5 \mathrm{~g}$ peptone; $5 \mathrm{~g}$ yeast extract; $1 \mathrm{~g} \mathrm{~K}_{2} \mathrm{HPO}_{4} ; 0.2 \mathrm{~g} \mathrm{MgSO}_{4} .7 \mathrm{H}_{2} \mathrm{O} ; 10 \mathrm{~g} \mathrm{Na}_{2} \mathrm{CO}_{3}$ (separately autoclaved); and $15 \mathrm{~g}$ agar (if needed). Strain $324^{\mathrm{T}}$ was cultivated at $37^{\circ} \mathrm{C}$ for $24 \mathrm{~h}$ on trypticase soy agar for fatty acid methyl ester analysis and on BUGM (Biolog) supplemented with $1 \%(\mathrm{w} / \mathrm{v})$ glucose for the Biolog substrate utilization test.

Morphological and physiological tests. The morphology of cells was examined by phase-contrast microscopy. Flagellum type was examined with transmission electron microscopy using cells from $24 \mathrm{~h}$ culture. The cells were negatively stained with $1 \%(\mathrm{w} / \mathrm{v})$ phosphotungstic acid and, after air drying, the grids were examined using a model CM-20 transmission electron microscope (Philips). Motility was observed by the hanging-drop method (Skerman, 1967). Catalase activity was determined by bubble production in a $3 \%(v / v) \mathrm{H}_{2} \mathrm{O}_{2}$ solution. Oxidase activity was determined by oxidation of $1 \%(\mathrm{w} / \mathrm{v})$ tetramethyl-p-phenylenediamine. Hydrolyses of gelatin, casein and starch, and production of urease were determined as described previously (Cowan \& Steel, 1965). Hydrolysis of aesculin was determined according to the method of Kurup \& Fink (1975). Tests for utilization of substrates as sole carbon source were performed with GP Biolog microplates containing 95 different carbon compounds. The results were checked over $48 \mathrm{~h}$.

Isolation of DNA. Chromosomal DNA was isolated by a previously described method (Yoon et al., 1996).

Chemotaxonomic characterizations. The diamino acid of the peptidoglycan was determined by a previously described method (Komagata \& Suzuki, 1987). Menaquinones were analysed as described previously (Komagata \& Suzuki, 1987) by reversed-phase HPLC. Fatty acids were extracted and analysed according to the instructions of the Microbial Identification System (MIDI; Microbial ID).

Determination of $\mathbf{G}+\mathbf{C}$ content. The $\mathrm{G}+\mathrm{C}$ content was determined by a previously described method (Tamaoka \& Komagata, 1984). DNA was enzymically hydrolysed and dephosphorylated; the resultant nucleosides were analysed by HPLC.

16S rDNA sequencing. 16S rDNA sequencing of strain $324^{\mathrm{T}}$ was performed as described previously (Yoon et al., 1997). The PCR products were recovered by precipitating with 2 propanol and the strands containing phosphorylated primer from PCR products were selectively digested using $\lambda$ exonuclease according to the instructions included with Strandase ssDNA Preparation kit (Novagen). The ssDNA templates produced were directly used for the sequencing reaction. The sequencing was performed as described previously (Kim et al., 1995) using $\alpha-{ }^{35}$ S-labelled dATP and a DNA sequencing kit (US Biochemical). The sequencing primers were derived from conserved regions of previously described 16S rRNA gene sequences of eubacteria.

Phylogenetic analysis. The 16S rDNA sequence of strain $324^{\mathrm{T}}$ was aligned with the $16 \mathrm{~S}$ rRNA and $16 \mathrm{~S}$ rDNA sequences of other Paenibacillus species and some other taxa using CLUSTAL w software (Thompson et al., 1994). Other reference sequences, obtained from the GenBank database, had the following accession numbers: X60632 (Paenibacillus polymyxa); D78318 (Paenibacillus azotofixans); D78476 (Paenibacillus peoriae); D78319 (Paenibacillus macerans); X77846 (Paenibacillus durum); D78473 (Paenibacillus lautus NRRL NRS-666 ${ }^{\mathrm{T}}$ ); D85609 (Paenibacillus lautus NRRL B377); D85394 (P. lautus NRRL B-379); D78470 (Paenibacillus glucanolyticus DSM 5162T); D88514 (P. glucanoly- ticus DSM 5188); D85395 (Paenibacillus chibensis); X60625 (Paenibacillus macquariensis); X60630 (Paenibacillus pabuli);D85396(Paenibacillus amylolyticus); D85397(Paenibacillus illinoisensis); D78317 (Paenibacillus alvei); U49247 (Paenibacillus apiarius); D78475 (Paenibacillus thiaminolyticus); D78466 (Paenibacillus curdlanolyticus); D78471 (Paenibacillus kobensis); D78320 (Paenibacillus validus); D82064 (Paenibacillus chondroitinus); D78465 (Paenibacillus aliginolyticus); X60636 (Paenibacillus larvae subsp. pulvifaciens); X60619 (P. larvae subsp. larvae); X60646 (Bacillus subtilis); D16266 (Bacillus cereus); D78312 (Bacillus circulans); X60629 (Bacillus megaterium); D78313 (Bacillus coagulans); X62174 (Halobacillus halophilus); D82065 (Amphibacillus xylanus); D78455 (Aneurinibacillus aneurinolyticus); D78457 (Brevibacillus brevis); X60742 (Alicyclobacillus acidocaldarius); and V00348 (Escherichia coli). The $16 \mathrm{~S}$ rDNA similarity values were calculated from the alignments and the evolutionary distances were calculated using the Kimura two-parameter correction with the CLUSTAL W package (Thompson et al., 1994). A phylogenetic tree was constructed using the neighbour-joining method (Saitou \& Nei, 1987) and the distance matrix data. A bootstrap analysis with 1000 replications for evaluating the topology of the phylogenetic tree was performed with the CLUSTAL w package (Thompson et al., 1994).

The GenBank accession number for the 16S rDNA sequence of strain $324^{\mathrm{T}}$ is AF021924.

\section{RESULT AND DISCUSSION}

\section{Morphological and physiological characteristics}

Cells were rod-shaped measuring $0.6-0.9$ by $3 \cdot 0-6.0 \mu \mathrm{m}$ in $48 \mathrm{~h}$ culture grown at $37^{\circ} \mathrm{C}$. They produced ellipsoidal spores in swollen sporangia. Colonies were flat, smooth and opaque. Strain $324^{\mathrm{T}}$ formed motile microcolonies during growth on wet agar plates. However, this characteristic was weak at $45^{\circ} \mathrm{C}$ and on completely dried agar plates. Strain $324^{\mathrm{T}}$ was facultatively anaerobic, Gram-variable and motile by means of peritrichous flagella (Fig. 1). Strain $324^{\mathrm{T}}$ had catalase activity, but no oxidase and urease activities.

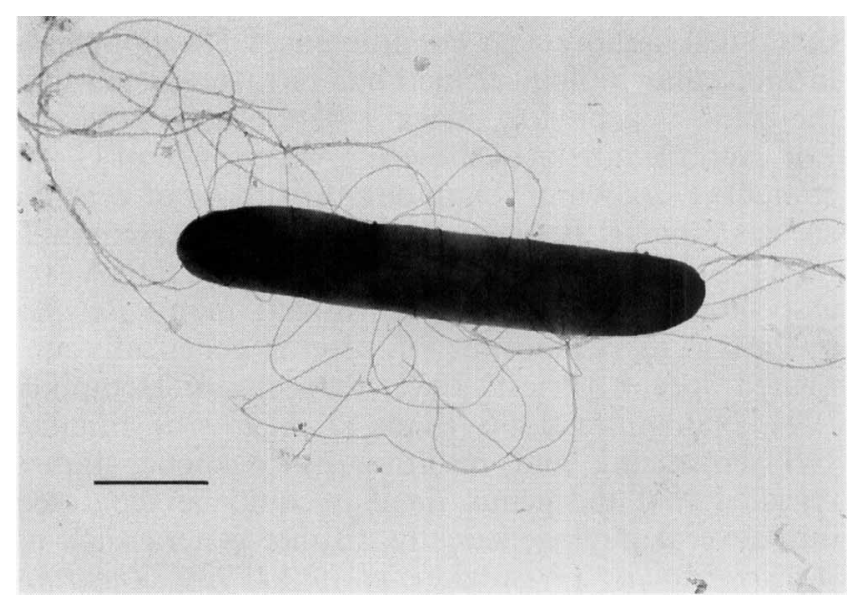

Fig. 1. Transmission electron micrograph of strain $324^{\top}$ from a $24 \mathrm{~h}$ culture. Bar, $1 \mu \mathrm{m}$. 
Table 1. Substrates oxidized as sole carbon source by strain $324^{\top}$

+ , Oxidized;,- not oxidized; w, weak reaction.

\begin{tabular}{|c|c|c|c|c|c|}
\hline Substrate & Reaction & Substrate & Reaction & Substrate & Reaction \\
\hline Carbohydrates: & & Psicose & w & Propionic acid & + \\
\hline$N$-Acetyl-D-glucosamine & - & D-Raffinose & - & Pyruvic acid & + \\
\hline$N$-Acetyl-D- & - & L-Rhamnose & - & Succinamic acid & - \\
\hline mannosamine & & D-Ribose & + & Succinic acid & - \\
\hline Amygdalin & - & Salicin & - & Alcohols: & \\
\hline L-Arabinose & + & Sedoheptulosan & - & 2,3-Butanediol & - \\
\hline Arabitol & - & D-Sorbitol & + & Glycerol & - \\
\hline Arbutin & - & Stachyose & - & Amino acids: & \\
\hline Cellobiose & - & Sucrose & - & D-Alanine & - \\
\hline$\alpha$-Cyclodextrin & - & Tagatose & + & L-Alanine & - \\
\hline$\beta$-Cyclodextrin & + & D-Trehalose & - & L-Alanyl-glycine & - \\
\hline Dextrin & - & Turanose & - & L-Asparagine & - \\
\hline D-Fructose & + & Xylitol & - & L-Glutamic acid & - \\
\hline D-Fucose & - & D-Xylose & + & Glycyl-L-glutamic acid & - \\
\hline L-Fucose & - & Esters: & & L-Pyroglutamic acid & - \\
\hline D-Galactose & - & Methylpyruvate & - & L-Serine & - \\
\hline Gentiobiose & - & Mono-methylsuccinate & - & Nucleosides: & \\
\hline D-Glucose & w & D-Lactic acid methyl & - & Adenosine & - \\
\hline Glycogen & w & ester & & 2-Deoxyadenosine & - \\
\hline$m$-Inositol & - & Detergents: & & Inosine & - \\
\hline Inulin & - & Tween 40 & + & Thymidine & - \\
\hline Lactose & - & Tween 80 & - & Uridine & - \\
\hline Lactulose & - & Carboxylic acids: & & Nucleotides: & \\
\hline Maltose & - & Acetic acid & + & Adenosine $5^{\prime}-$ & - \\
\hline Maltotriose & - & $N$-Acetyl-L-glutamic acid & - & monophosphate & \\
\hline Mannan & - & D-Galacturonic acid & - & Thymidine $5^{\prime}-$ & - \\
\hline Mannitol & - & D-Gluconic acid & - & monophosphate & \\
\hline D-Mannose & - & $\alpha$-Hydroxybutyric acid & - & Uridine $5^{\prime}-$ & - \\
\hline D-Melezitose & - & $\beta$-Hydroxybutyric acid & - & monophosphate & \\
\hline Melibiose & + & $\gamma$-Hydroxybutyric acid & - & Phosphorylated compounds: & \\
\hline Methyl $\alpha$-D-galactoside & - & $\rho$-Hydroxyphenyl acetic & - & Fructose 6-phosphate & + \\
\hline Methyl $\beta$-D-galactoside & - & acid & & Glucose 1-phosphate & - \\
\hline 3-Methylglucose & w & $\alpha$-Ketoglutaric acid & - & Glucose 6-phosphate & w \\
\hline Methyl $\alpha$-D-glucoside & - & $\alpha$-Ketovaleric acid & - & DL- $\alpha$-Glycerol phosphate & - \\
\hline Methyl $\beta$-D-glucoside & - & L-Lactic acid & - & Putrescine & - \\
\hline Methyl $\alpha$-D-mannoside & - & D-Malic acid & - & Alaninamide & - \\
\hline Palatinose & - & L-Malic acid & - & Lactamide & - \\
\hline
\end{tabular}

This strain grew in the presence of $7 \%(\mathrm{w} / \mathrm{v}) \mathrm{NaCl}$, whereas most Paenibacillus species failed to grow in the presence of $5 \%(\mathrm{w} / \mathrm{v}) \mathrm{NaCl}$ (Shida et al., 1997a). Gelatin, casein, aesculin and starch were hydrolysed. Strain $324^{\mathrm{T}}$ grew at 10 and $45^{\circ} \mathrm{C}$, but not at 5 and $50^{\circ} \mathrm{C}$. The optimum growth temperature was $40^{\circ} \mathrm{C}$. In contrast, the optimum growth temperature for all Paenibacillus species, except $P$. macquariensis, was 28-30 ${ }^{\circ} \mathrm{C}$ (Shida et al., 1997a). P. macquariensis had an optimum growth temperature of $20-23{ }^{\circ} \mathrm{C}$ (Shida et al., 1997a). Strain $324^{\mathrm{T}}$ was alkaliphilic. This strain did not grow at $\mathrm{pH} 7$, but grew at $\mathrm{pH} 7 \cdot 5-10 \cdot 5$. The optimum $\mathrm{pH}$ for growth was 10 ; members of the genus Paenibacillus grew optimally at $\mathrm{pH} 7 \cdot 0$ (Shida et al., $1997 \mathrm{a}$ ). The alkaliphilic property of strain $324^{\mathrm{T}}$ was an important phenotypic difference that distinguished strain $324^{\mathrm{T}}$ from the known Paenibacillus species. The results of utilization of substrates as sole carbon sources for respiration (formation of NADH) on Biolog microplates are shown in Table 1.

\section{Chemotaxonomic characteristics and DNA base composition}

meso-Diaminopimelic acid was the diamino acid found in the cell-wall peptidoglycan of strain $324^{\mathrm{T}}$. This diamino acid also appeared in the members of the genus Paenibacillus (Shida et al., 1997a). Other aerobic endospore formers such as Bacillus, Sporolactobacillus and Amphibacillus also contained meso-diaminopi- 


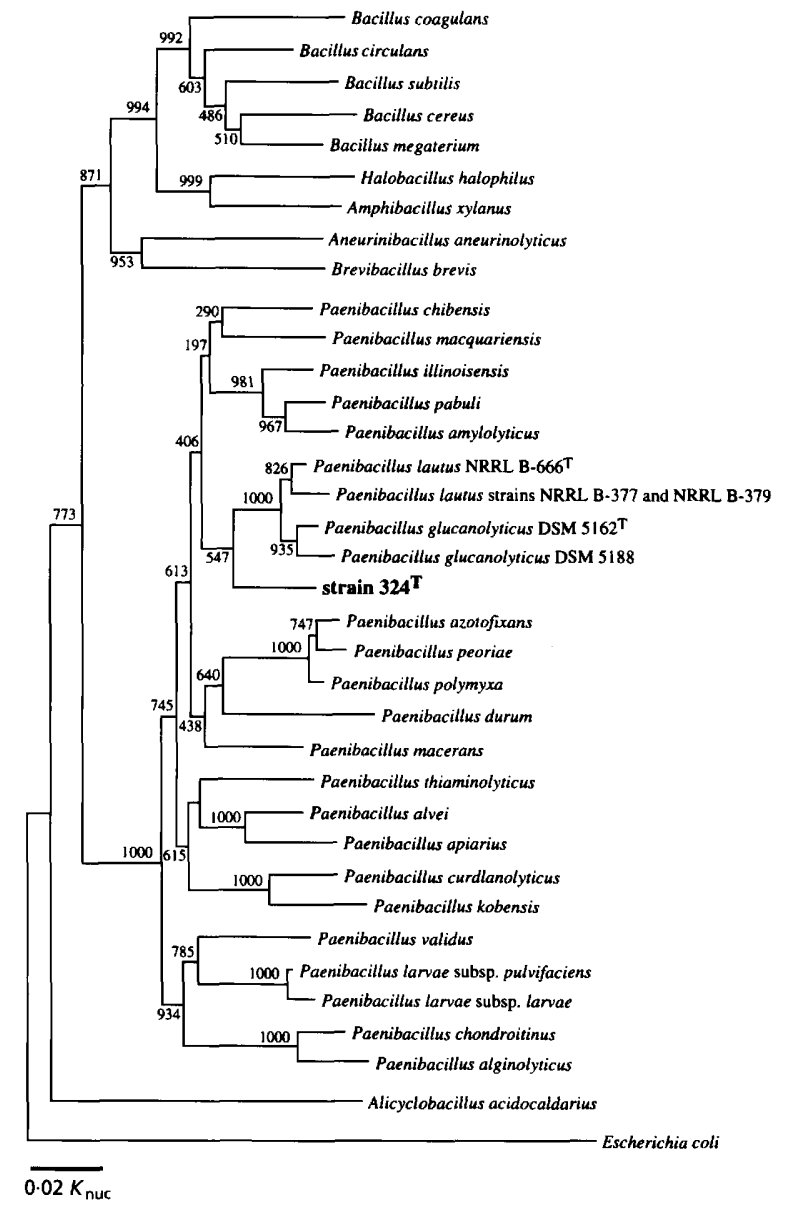

Fig. 2. Phylogenetic tree showing the position of strain $324^{\top}$ in relation to Paenibacillus species and some rod-shaped, endospore-forming bacteria based on 16S rRNA gene sequences. Bootstrap values are indicated. Bar, 2 nucleotide substitutions per 100 nucleotides.

melic acid in their cell-walls (Shida et al., 1997a). The major isoprenoid quinone was MK-7, which is the major menaquinone generally found in aerobic, endospore-forming rods. Anteiso- $\mathrm{C}_{15: 0}(53 \%)$, the predominant fatty acid found in the genus Paenibacillus, was also the major component of strain $324^{\mathrm{T}}$ fatty acids. Although other aerobic, endospore-forming genera also contained large amounts of anteiso- $\mathrm{C}_{15: 0}$ fatty acid, they simultaneously contained significant amounts of other fatty acids (Shida et al., 1997a).

The $\mathrm{G}+\mathrm{C}$ content of strain $324^{\mathrm{T}}$ was $50.9 \mathrm{~mol} \%$, a level included within the range found in the members of the genus Paenibacillus (Shida et al., 1997a).

\section{Phylogenetic analysis}

Although the preceding chemotaxonomic, $\mathrm{G}+\mathrm{C}$ content and biochemical analyses did not establish a definitive taxonomic position for strain $324^{\mathrm{T}}$, they suggested Paenibacillus as a possible classification. $16 \mathrm{~S}$ rDNA was sequenced to verify the suggestion. An almost complete $16 \mathrm{~S}$ rDNA sequence (1508 bp), which corresponds to a region between positions 28 and 1524 by comparison with the $E$. coli $16 \mathrm{~S}$ rRNA gene, was directly sequenced. The phylogenetic tree (Fig. 2) constructed from the sequence data shows that strain $324^{\mathrm{T}}$ appeared within the evolutionary radiation encompassing the genus Paenibacillus and occupied a distinct phylogenetic position within the genus. Levels of $16 \mathrm{~S}$ rDNA similarity between strain $324^{\mathrm{T}}$ and the Paenibacillus species were $90 \cdot 6-95 \cdot 9 \%$. The highest 16S rDNA sequence similarities of $95 \cdot 2-95 \cdot 9 \%$ were observed between strain $324^{\mathrm{T}}$ and $P$. lautus, and between strain $324^{\mathrm{T}}$ and P. glucanolyticus. The phylogenetic definition states that 'strains with approximately $70 \%$ or greater DNA-DNA relatedness' are members of the same species (Wayne et al., 1987). According to the available compilation of data by Stackebrandt \& Goebel (1994), organisms that have less than $97.0 \% 16 \mathrm{~S}$ rDNA or 16S rRNA similarities will not reassociate to more than $60 \%$, no matter which hybridization method is used. The phylogenetic study clearly established that strain $324^{\mathrm{T}}$ was a Paenibacillus species.

The phenotypic, chemotaxonomic and phylogenetic data showed that strain $324^{\mathrm{T}}$ belonged to the genus Paenibacillus. Moreover, phenotypic uniqueness imparted by the alkaliphilic and moderately thermophilic nature of the strain and genetic distinctiveness inferred from the phylogenetic study warranted the proposal of strain $324^{\mathrm{T}}$ as a new species, Paenibacillus campinasensis $\mathrm{sp}$. nov.

\section{Description of Paenibacillus campinasensis sp. nov.}

Paenibacillus campinasensis (cam.pi.na.sen'sis. M.L. adj. campinasensis referring to Campinas, the city where the College of Food Engineering, State University of Campinas, Brazil, is located).

Cells are rods measuring $0 \cdot 6-0.9$ by $3 \cdot 0-6.0 \mu \mathrm{m}$ and motile by means of peritrichous flagella. Ellipsoidal spores are formed in swollen sporangia. Colonies are flat, smooth and opaque. Forms motile microcolonies on wet agar plates. Facultatively anaerobic and Gramvariable. Catalase-positive and oxidase- and ureasenegative. Growth occurs in the presence of $7 \% \mathrm{NaCl}$. Gelatin, casein, aesculin and starch are hydrolysed. Utilizes L-arabinose, $\beta$-cyclodextrin, D-fructose, $\mathrm{D}$ glucose, melibiose, 3-methylglucose, psicose, D-ribose, D-sorbitol, tagatose, D-xylose, Tween 40 , acetic acid, propionic acid, pyruvic acid, fructose 6-phosphate and glucose 6-phosphate as sole carbon sources for respiration. Substrates which are not utilized are shown in Table 1. Grows at 10 and $45^{\circ} \mathrm{C}$, but not at 5 and $50{ }^{\circ} \mathrm{C}$; optimum temperature is $40^{\circ} \mathrm{C}$. Alkaliphilic. Does not grow at $\mathrm{pH} 7$. Grows at $\mathrm{pH} 7 \cdot 5-10 \cdot 5$; optimum $\mathrm{pH}$ is 10 . Cell-wall peptidoglycan contains meso-diaminopimelic acid. The major isoprenoid quinone is a menaquinone, MK-7. The major fatty acid is anteiso- $\mathrm{C}_{15: 0}$. The $\mathrm{G}+\mathrm{C}$ content is $50.9 \mathrm{~mol} \%$ (de- 
termined by HPLC). The type strain is $324^{\mathrm{T}}$, which was isolated in Brazil. The type strain has been deposited in the Korean Collection for Type Cultures as KCTC 0364BP ${ }^{\mathrm{T}}$.

\section{ACKNOWLEDGEMENTS}

This work was supported by grant HS1331 from the Ministry of Science and Technology of the Republic of Korea. We are grateful to Dr Yong Kook Shin, Keunchul Lee and Dr Akio Seino for helpful discussions.

\section{REFERENCES}

Ash, C., Priest, F. G. \& Collins, M. D. (1993). Molecular identification of rRNA group 3 bacilli (Ash, Farrow, Wallbanks, and Collins) using a PCR probe test. Proposal for the creation of a new genus Paenibacillus. Antonie Leeuwenhoek 64, 253-260.

Claus, D. \& Berkeley, R. C. W. (1986). Genus Bacillus Cohn 1872. In Bergey's Manual of Systematic Bacteriology, vol. 2, pp. 1105-1140. Edited by P. H. A. Sneath, N. S. Mair, M. E. Sharpe \& J. G. Holt. Baltimore: Williams \& Wilkins.

Cowan, S. T. \& Steel, K. J. (1965). Manual for the Identification of Medical Bacteria. London: Cambridge University Press.

Kim, S.-B., Yoon, J.-H., Kim, H., Lee, S.T., Park, Y.-H. \& Goodfellow, M. (1995). A phylogenetic analysis of the genus Saccharomonospora conducted with 16S rRNA gene sequences. Int J Syst Bacteriol 45, 351-356.

Komagata, K. \& Suzuki, K. (1987). Lipids and cell-wall analysis in bacterial systematics. Methods Microbiol 19, 161-203.

Kurup, V. P. \& Fink, J. N. (1975). A scheme for the identification of thermophilic actinomycetes associated with hypersensitivity pneumonitis. J Clin Microbiol 2, 55-61.

Nakamura, L. K. (1996). Paenibacillus apiarius sp. nov. Int J Syst Bacteriol 46, 688-693.

Priest, F. G. (1981). DNA homology in the genus Bacillus. In The Aerobic Endospore-forming Bacteria, pp. 33-57. Edited by R. C. Berkeley \& M. Goodfellow. London: Academic Press.

Saitou, N. \& Nei, M. (1987). The neighbor-joining method: a new method for reconstructing phylogenetic trees. Mol Biol Evol 4, $406-425$.

Shida, O., Takagi, H., Kadowaki, K. \& Komagata, K. (1996). Proposal for two new genera, Brevibacillus gen. nov. and Aneurinibacillus gen. nov. Int J Syst Bacteriol 46, 939-946.

Shida, O., Takagi, H., Kadowaki, K., Nakamura, L. K. \& Komagata, K. (1997a). Transfer of Bacillus alginolyticus, Bacillus chondroitinus, Bacillus curdlanolyticus, Bacillus glucanolyticus, Bacillus kobensis, and Bacillus thiaminolyticus to the genus Paenibacillus and emended description of the genus Paenibacillus. Int J Syst Bacteriol 47, 289-298.
Shida, O., Takagi, H., Kadowaki, K., Nakamura, L. K. \& Komagata, K. (1997b). Emended description of Paenibacillus amylolyticus and description of Paenibacillus illinoisensis sp. nov. and Paenibacillus chibensis sp. nov. Int J Syst Bacteriol 47, 299-306.

Skerman, V. B. D. (1967). A Guide to the Identification of the Genera of Bacteria, 2nd edn. Baltimore: Williams \& Wilkins.

Slepecky, R. A. \& Hemphill, H. E. (1991). The genus Bacillus nonmedical. In The Prokaryotes, pp. 1663-1696. Edited by A. Balows, H. G. Trüper, M. Dworkin, W. Harder \& K.-H. Schleifer. New York: Springer.

Spring, S., Ludwig, W., Marquez, M. C., Ventosa, A. \& Schleifer, K.-H. (1996). Halobacillus gen. nov., with description of Halobacillus litoralis sp. nov. and Halobacillus truperi sp. nov., and transfer of Sporosarcina halophilia to Halobacillus halophilus comb. nov. Int J Syst Bacteriol 46, 492-496.

Stackebrandt, E. \& Goebel, B. M. (1994). Taxonomic note: a place for DNA-DNA reassociation and 16S rRNA sequence analysis in the present species definition in bacteriology. Int $J$ Syst Bacteriol 44, 846-849.

Stackebrandt, E. \& Liesack, W. (1993). Nucleic acids and classification. In Handbook of New Bacterial Systematics, pp. 152-189. Edited by M. Goodfellow \& A. G. O'Donnell. London: Academic Press.

Tamaoka, J. \& Komagata, K. (1984). Determination of DNA base composition by reverse-phase high-performance liquid chromatography. FEMS Microbiol Lett 25, 125-128.

Thompson, J. D., Higgins, D. G. \& Gibson, T. J. (1994). CLUSTAL W : improving the sensitivity of progressive multiple sequence alignment through sequence weighting, position specific gap penalties and weight matrix choice. Nucleic Acids Res 22 , 4673-4680.

Wayne, L. G., Brenner, D. J., Colwell, R. R. \& 9 other authors (1987). International Committee on Systematic Bacteriology. Report of the ad hoc committee on reconciliation of approaches to bacterial systematics. Int J Syst Bacteriol 37, 463-464.

Wisotzkey, J. D., Jurtshuk, P., Jr, Fox, G. E., Deinhard, G. \& Poralla, K. (1992). Comparative sequence analysis on the $16 \mathrm{~S}$ rRNA (rDNA) of Bacillus acidocaldarius, Bacillus acidoterrestris, and Bacillus cycloheptanicus and proposal for creation of a new genus, Alicyclobacillus gen. nov. Int J Syst Bacteriol 42, 263-269.

Yim, D. G., Sato, H. H., Park, Y.-H. \& Park, Y. K. (1997). Production of cyclodextrin from starch by cyclodextrin glycosyltransferase from Bacillus firmus and characterization of purified enzyme. $J$ Ind Microbiol Biotechnol 18, 402-405.

Yoon, J.-H., Kim, H., Kim, S.-B., Kim, H.-J., Kim, W. Y., Lee, S. T., Goodfellow, M. \& Park, Y.-H. (1996). Identification of Saccharomonospora strains by the use of genomic DNA fragments and rRNA gene probes. Int $J$ Syst Bacteriol 46, 502-505.

Yoon, J.-H., Lee, J.-S., Shin, Y. K., Park, Y.-H. \& Lee, S. T. (1997). Reclassification of Nocardioides simplex ATCC 13260, ATCC 19565, and ATCC 19566 as Rhodococcus erythropolis. Int J Syst Bacteriol 47, 904-907. 